\title{
Electronic structure of large modified nickel nanoclusters
}

\author{
V.Pokhmurskii, V.Kopylets, S.Korniy \\ Physics and Mechanics Institute of NAS of Ukraine, 5, Naukowa Str., 79601 Lviv, Ukraine
}

Received January 26, 2006, in final form November 20, 2006

\begin{abstract}
A combined method of quantum-chemical semiempirical approach MNDO and molecular dynamics with atomic potentials was used while studying the growth of large nanoclusters of nickel. Geometry and electronic structure of $\mathrm{Ni}_{485}$ were studied as well as a series of similar surface (111) substituted (by Pd, Pt, $\mathrm{Cu}, \mathrm{Mn}$ and $\mathrm{Cr}$ ) clusters. The role was analysed of the surface electronic density of states (DOS) and their contribution into the processes such as adsorption and surface reaction at catalytic oxidation of carbon monoxide. Stability of all substituted nanoclusters was analyzed and surface electron charges were estimated as negligible in agreement with experiments and exact calculations by periodic ab initio methods.
\end{abstract}

Key words: quantum-chemical and molecular dynamics calculations, nanoclusters, density of states, catalytic processes, surface

PACS: $81.16 . H c, 73.22 .-f$

\section{Introduction}

Both semiempirical and ab initio quantum chemical methods are widely used in the study of electronic and geometrical structures of large molecules and clusters [1]. However in the case of ab initio approximations, powerful computers and workstations are required. The situation is complicated when quantum chemical Hamiltonians are introduced into the statistical molecular dynamic and Monte Carlo methods. These are needed to obtain a vivid time-dependent picture of nanocluster development, such as growth and interaction with environment [2]. An attempt to use standard software (HyperChem [3], etc.) frequently fails due to computational problems. The information about the change of electron dependent properties would be extremely useful in preparing the molecules and nanoclusters with new behavior in different fields of physics and chemistry.

In the present study we managed to use a combined method of semi-empirical quantum chemical and molecular dynamic statistical approximations [4] to calculate equilibrium geometry and electronic structures by means of personal computer hardware. This simulation makes it possible to use such an approximation in many researches in a simple and effective manner within short computer times.

\section{Computer model}

As it was done previously [4], we used a modified version of the HyperChem 6.0 temporary and GAMESS [5] software with intrinsic parameters for transition metals [6] by means of the MNDO method. Large clusters of nickel were constructed on the basis of its elementary f.c.c. cells to form a final cubo-octahedral structure with large (111) surfaces. The surface atoms of nickel were subsequently substituted by other atoms ( $\mathrm{Pt}, \mathrm{Pd}, \mathrm{Cu}, \mathrm{Mn}$ and $\mathrm{Cr}$ ) to follow the alteration of the basis cluster electronic properties. The clusters of 13 and 55 atoms were also calculated as they had structural stability. Large clusters contained up to 500 atoms, the formation of 485 atoms being stable in a cubo-octahedral structure. 


\section{Results and discussion}

In figure 1 we show the tendency of cluster stabilization with the growth of its sizes in all three directions. At the beginning, the formations are relatively stable only for several atoms since optimization of geometry is allowed completely. In the middle section a decay of an initial unoptimized structures is observed (with the exclusion of $\mathrm{Ni}_{13}$ and $\mathrm{Ni}_{55}$ ). The stability may be obtained if the number of atoms reaches three hundred and more. Bulk lattice parameter for such a nickel cluster is $0.315 \mathrm{~nm}$ and is in good agreement with the experimental value 0.352 [7]. The calculated value is natural for such semiempirical method.

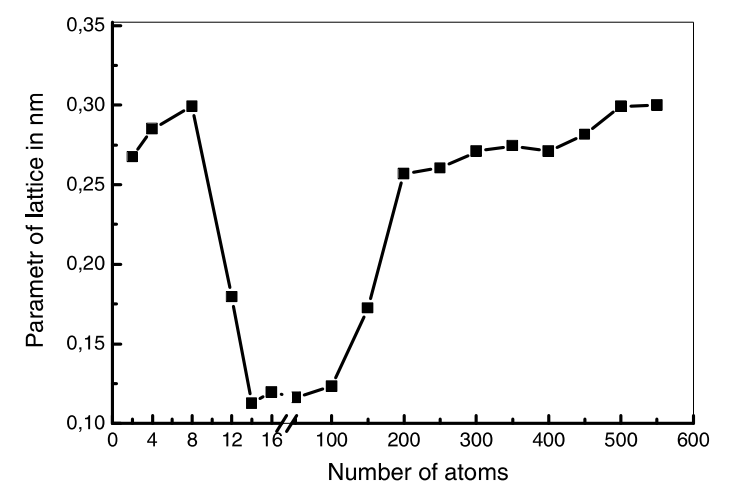

Figure 1. Dependence of the calculated parameter of a lattice nickel nanocluster on the number of atoms.

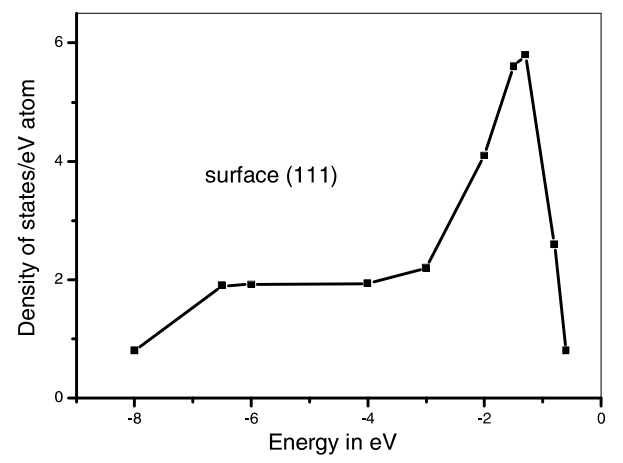

(a)

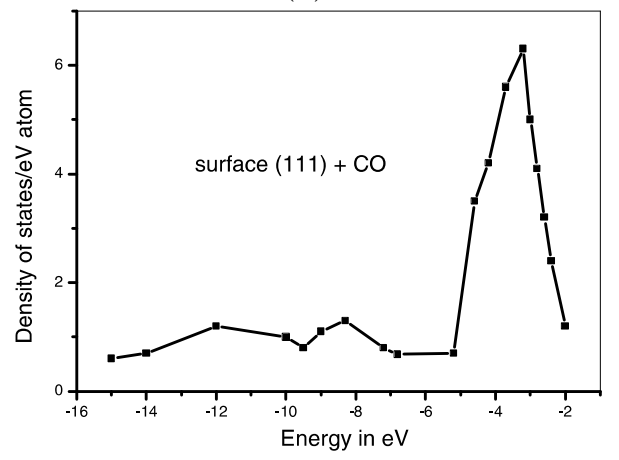

(c)

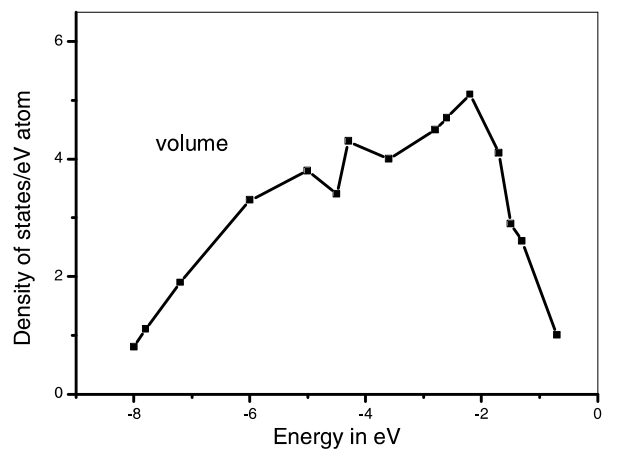

(b)

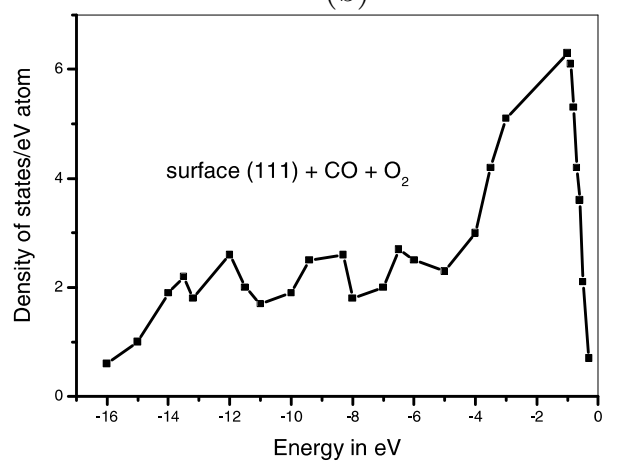

(d)

Figure 2. Density of states as a function of energy: a) - surface (111) of $\mathrm{Ni}_{485}$ cluster; b) - volume of the cluster (second layer and others); c) - surface (111), covered with CO molecules in atop sites; d) - surface (111) with $\mathrm{CO}$ and $\mathrm{O}_{2}$ chemisorbed ( $\mathrm{CO}-$ atop, $\mathrm{O}_{2}-$ in bridge positions. (c) and d) are presented with $s-p$-band as low peaks). 
The density of states (DOS) was calculated as a function of energies and the influence of surface (111), volume and gas chemisorption on DOS was determined for stable structure. Figure 2 shows the results for pure nickel cluster $\mathrm{Ni}_{485}$.

Part $a$ and $b$ of the figure 2 present the difference in DOS between the surface (111) and volume (second layer) of the cluster. We see more wide peaks for the latter case. The main peak is also lower here. We showed the density of states for $d$-orbitals. If adsorbat is present, the Fermi level is shifted to the left (more negative values): CO causes the emergence of two main groups of peaks from $s-p$-electrons while $\mathrm{CO}+\mathrm{O}_{2}$ causes four of them (part $c$ and $d$ ).

The results indicate that only the surface is effected and the behavior of the second and the next layers almost coincides with that of volume. Due to self-consistent calculations, the charge transfer and values of orbital occupation are easily obtained which enabled us to study the peculiarities of the surface and the adsorbat.

A perspective view of nickel $\mathrm{Ni}_{485}$ (figure 3) is presented with two adsorption sites - atop and bridge positions, the latter being shown for similar reaction [9] on the surface (110) of $\mathrm{RuO}_{2}$.

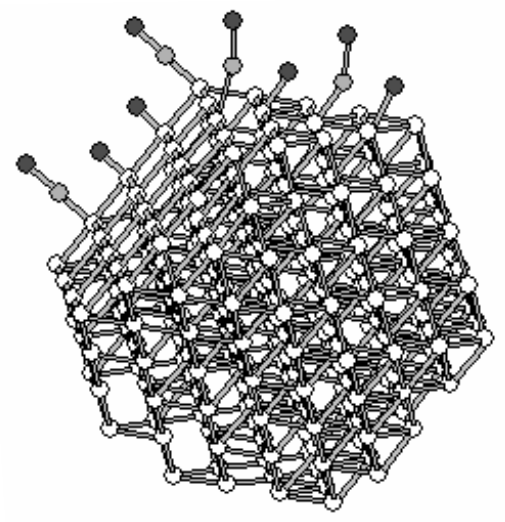

Figure 3. A perspective view of $\mathrm{CO}$ and $\mathrm{O}_{2}$ (dissociative) adsorption on the (111) surface of $\mathrm{Ni}_{485}$ nanocluster on atop (left side) and bridge (upper side) positions.

Next we modified the nickel cluster with noble (Pd and Pt) metal atoms (up to 10\%) to change its electronic properties. The substitution of surface atoms really alters the DOS of nickel cluster and the shift of energy levels becomes more favorable for surface reaction activation. Thus the oxidation of carbon monoxide becomes more intensive and the catalytic properties of large nanoclusters are improved. However the newly formed structure is slightly unstable (95\% as compared with pure nickel cluster. The implantation of inactive copper atoms (up to 10\%) makes the cluster of worse stability (73\%). On the other hand, the substitution of surface nickel atoms with $\mathrm{Cr}$ and $\mathrm{Mn}$ presented a nice stability, though the catalytic activity was just a little lost, as compared with pure $\mathrm{Ni}_{485}$. This may be explained by a decrease in energy level shift in contrast to noble metal effect.

Table 1. Electron excess in the surface (111) for pure nickel cluster and clusters with $10 \%$ content of other transition metals.

\begin{tabular}{|l|l|l|l|l|l|l|}
\hline Nanocluster & $\mathrm{Ni}_{485}$ & $\mathrm{Ni}+\mathrm{Pd}$ & $\mathrm{Ni}+\mathrm{Pt}$ & $\mathrm{Ni}+\mathrm{Cu}$ & $\mathrm{Ni}+\mathrm{Cr}$ & $\mathrm{Ni}+\mathrm{Mn}$ \\
\hline $\begin{array}{l}\text { Electron excess in } \\
\text { the surface (elec- } \\
\text { tron/Ni atom) }\end{array}$ & 0,032 & 0,035 & 0,040 & 0,021 & 0,026 & 0,028 \\
\hline
\end{tabular}

The substitution of surface nickel atoms by $\mathrm{Cu}, \mathrm{Cr}$ and $\mathrm{Mn}$ makes the active surface oxidation possible and serves as an example of $d$ - and $s-p$-electron effect on the transfer, which causes the loss of catalytic activity of nickel nanocluster. 
In calculations we observed a negligible excess of electrons in the surface gathered in the table 1. It may be noticed that noble metals increase the nickel atom charge, and accelerate surface processes such as chemisorption and surface reactions, $2 \mathrm{CO}+\mathrm{O}_{2}=2 \mathrm{CO}_{2}$.

Other transition elements, such as $\mathrm{Cr}$ and $\mathrm{Mn}$ decrease the electron charge on nickel atoms, particularly $\mathrm{Cu}$, and they decrease activation of the nanocluster. The change distribution is in satisfactory agreement with exact periodic ab initio calculations [8].

\title{
4. Conclusions
}

A combined method of quantum chemical semiempirical MNDO approximation and molecular dynamics made it possible to study the process of large metal nanocluster formation, indicating some stable structures, $\mathrm{Ni}_{13}$ and $\mathrm{Ni}_{55}$ (known before) and a new $\mathrm{Ni}_{485}$. The substitution of surface atoms in the cluster by other transition metals causes the change of their geometry stability. The analysis of electronic structures of the clusters showed the role of density of states, separated into $\mathrm{d}$ - and sp- band, which is important in the surface processes, which determine the catalytic activity with important practical applications (utilization of harmful gases and liquids, chemical synthesis).

\section{References}

1. Stampfl C., Ganduglia-Pirovano M.V., Reuter K., Scheffler M., Surf. Sci., 2002, 500, 368.

2. Valuev A.A., Kaklugin A.S., Norman G.E., Uspechi chimiji, 1995, 64, 643.

3. http://www.hyper.com

4. Pokhmurskii V.I., Kopylets V.I., Korniy S.A., Phys.-Chim. Mech. Mater., 2004, 5, 7.

5. Schmidt M.S., Baldridge K.K., Boatz J.A. et al., J. Comput. Chem., 1993, 14, 1347.

6. Kopylets V.I., Korniy S.A., Phys.-Chim. Mech. Mater., 2002, 2, 120.

7. Roberts M.W., McKee C.S. Chemistry of the metal-gas interface, p. 113-115. Clarendon press, Oxford, 1980.

8. Smith J. Theory of chemisorption, p. 241-327. Springen-Verlag, Berlin, 1980.

9. Reuter K., Frenkel D., Scheffler M., Phys. Rev. Let., 2004, 93, 11, 116105-1.

\section{Електронна структура модифікованих нанокластерів нікелю}

\author{
В.І.Похмурський, В.І.Копилець, С.А.Корній \\ Фізико-механічний інститут ім. Г.В.Карпенка НАН України, 79061, м. Львів, вул. Наукова, 5 \\ Отримано 26 січня 2006 р., в остаточному вигляді - 20 листопада 2006 р.
}

\begin{abstract}
Вивчається процес росту великих нанокластерів нікелю із застосуванням комбінованого підходу на основі квантово-хімічного напівемпіричного MNDO методу та молекулярно-динамічного методу 3 атомними потенціалами. Досліджується геометрична та електронна структура нанокластера Ni485, а також модифікованих нанокластерів, утворених при заміщенні поверхневих атомів нікелю атомами паладію, платини, міді, марганцю та хрому. Проаналізовано роль поверхневих електронних станів під час адсорбційних процесів та поверхневих реакцій при каталітичному окисленні монооксиду вуглецю на поверхні нанокластерів нікелю. Досліджено стійкість нанокластерів та розраховано поверхневі електронні заряди, що узгоджуються з ab initio розрахунками періодичних структур.
\end{abstract}

Ключові слова: квантово-хімічні та молекулярно-динамічні розрахунки, нанокластери, густина станів, каталітичні процеси, поверхня

PACS: $81.16 . H c, 73.22 .-f$ 